\title{
Acyclic Diterpene Glycosides, Capsianosides VIII, IX, X, XIII, XV and XVI from the Fruits of Paprika Capsicum annuum L. var. grossum BAILEY and Jalapeño Capsicum annuum L. var. annuum
}

\author{
Jong-Hyun Lee, Naoko Kiyota, Tsuyoshi IkedA, and Toshihiro NoHARA* \\ Faculty of Medical and Pharmaceutical Sciences, Kumamoto University; 5-1 Oe-Honmachi, Kumamoto 862-0973, Japan. \\ Received March 13, 2006; accepted June 16, 2006
}

\begin{abstract}
Paprika and Jalapeño are used as vegetables and spices. We have obtained six new acyclic diterpene glycosides, called capsianosides XIII (2), XV (3), IX (4), XVI (5), X (6) and VIII (7) together with known capsianoside II (1) from the fruits of the Paprika and Jalapeño. The structures of these compounds have been elucidated by the ${ }^{1} \mathrm{H}$ - and ${ }^{13} \mathrm{C}$-NMR spectra and two-dimensional NMR methods.
\end{abstract}

Key words Paprika; Jalapeño; capsianoside; acyclic diterpene glycoside; Solanaceae; Capsicum annuum

Paprika is known for its high vitamin $\mathrm{C}$ content and has been isolated from Hungarian paprika in large amounts. ${ }^{1)}$ Jalapeño is a stimulating spice which contains capsaicin and related compounds in its fruits and veins. Carotenoids, ${ }^{2,3)}$ lipids and capsaicin $^{4)}$ have been well studied in the Capsicum species. Now our study has focused on the water-soluble constituents of Paprika and Jalapeño fruits. Previous studies in this laboratory led to the isolation of novel acyclic diterpene glycosides, capsianoside $\mathrm{A}-\mathrm{H}$ and $\mathrm{I}-\mathrm{VI}$ from Capsicum plants. ${ }^{5)}$ In this study, we isolated six new acyclic diterpene glycosides termed capsianosides XIII (2), XV (3), IX (4), XVI (5), X (6) and VIII (7) along with one known compound. ${ }^{5)}$ Since the known compound, capsianoside $\mathrm{II}^{5)}$ had an error in sugar sequence, we revised it. Distribution of these new compounds is summarized in Table 1.

Capsianoside II (1), an amorphous powder, $[\alpha]_{\mathrm{D}}-31.2^{\circ}$, showed peaks due to $[\mathrm{M}+\mathrm{Na}]^{+}$at $\mathrm{m} / \mathrm{z} 1108,[\mathrm{~m} / \mathrm{z} 1108$-deoxyhexose $]^{+}$at 962 and $[\mathrm{m} / \mathrm{z} \text { 962-hexose-deoxyhexose }]^{+}$at 654 in positive FAB-MS and gave a molecular formula $\mathrm{C}_{50} \mathrm{H}_{84} \mathrm{O}_{25} \mathrm{Na}$ at $m / z 1107.5374$ by HR-FAB-MS. Moreover, the ${ }^{1} \mathrm{H}-\mathrm{NMR}$ spectrum of $\mathbf{1}$ disclosed the presence of four methyl groups at $\delta 1.39(3 \mathrm{H}, \mathrm{s}), 1.61(6 \mathrm{H}, \mathrm{s})$ and $1.77(3 \mathrm{H}$, s), three olefinic protons at $\delta 5.22(1 \mathrm{H}$, brd $J=11.0 \mathrm{~Hz})$, $5.23(1 \mathrm{H}, \mathrm{brd}, J=18.3 \mathrm{~Hz})$ and $6.12(1 \mathrm{H}, \mathrm{dd}, J=11.0$, $18.3 \mathrm{~Hz}$ ) arising from a mono-substituted double bond, three olefinic protons at $\delta 5.12(2 \mathrm{H}, \mathrm{m})$ and $5.40(1 \mathrm{H}, \mathrm{t})$ adjacent to methylene group and seven methylene groups at $\delta 1.61$ $(2 \mathrm{H}, \mathrm{m}), 1.95-2.20(10 \mathrm{H}, \mathrm{m}), 4.13(1 \mathrm{H}, \mathrm{d}, J=11.6 \mathrm{~Hz})$ and $4.32(1 \mathrm{H}, \mathrm{d}, J=11.6 \mathrm{~Hz})$. The ${ }^{13} \mathrm{C}-\mathrm{NMR}$ spectrum of 1 as listed in Table 2 showed total twenty carbon signals composed of three tri-substituted double bonds at $\delta 125.8,125.9$, 131.2, 132.4, 135.5 and 136.0, a mono-substituted double bond at $\delta 116.0$ and 144.4, three methyl groups at $\delta 16.3$ $(2 \times C), 23.4$ and seven methylene groups. Since all the signals due to the aglycone moiety of capsianoside II (1) in the ${ }^{1} \mathrm{H}$ - and ${ }^{13} \mathrm{C}$-NMR spectra were identical with those of capsianoside A reported previously, ${ }^{5}$ the configuration at $\mathrm{C}-3$ was characterized as $S$. The above NMR signals were identical with those of the aglycone moiety, 17-hydroxy$6 E, 10 E, 14 Z$-(3S)-geranyl-linalool, of capsianoside II previously reported. ${ }^{5)}$ Other sapogenols of capsianosides XIII (2), IX (4), XVI (5), X (6) and VIII (7) were also coincident with that of 1 . The ${ }^{1} \mathrm{H}-\mathrm{NMR}$ spectrum due to the sugar part of $\mathbf{1}$ showed signals ascribable to $3 \mathrm{~mol}$ of hexosyl and $2 \mathrm{~mol}$ of deoxyhexosyl moieties from the evidence of signals ascribable to five anomeric protons at $\delta 4.21(1 \mathrm{H}, \mathrm{d}, J=7.3 \mathrm{~Hz})$, $4.47(1 \mathrm{H}, \mathrm{d}, J=7.3 \mathrm{~Hz}), 4.56(1 \mathrm{H}, \mathrm{d}, J=7.3 \mathrm{~Hz}), 4.71(1 \mathrm{H}, \mathrm{s})$ and $4.83(1 \mathrm{H}, \mathrm{s})$. The ${ }^{13} \mathrm{C}$-NMR spectra also exhibited five anomeric carbon signals at $\delta 105.9,102.7,102.2,101.6$ and 98.3. The following HMBC correlations shown in Fig. 1 revealed the sugar connections respectively: correlations between the signal at $\delta_{\mathrm{H}} 4.47(1 \mathrm{H}, \mathrm{d}, J=7.3 \mathrm{~Hz})$ and the signal at $\delta_{\mathrm{C}} 82.1$ (aglycone C-3) indicating the Glc I H-1 to be linked to the C-3 of the aglycone; the signal at $\delta_{\mathrm{H}} 4.56(1 \mathrm{H}$, d, $J=7.3 \mathrm{~Hz}$ ) and the signal at $\delta_{\mathrm{C}} 83.3$ (Glc I C-2) showing the Glc II H-1 to be linked to the C-2 of the Glc I; the signal at $\delta_{\mathrm{H}} 4.21(1 \mathrm{H}, \mathrm{d}, J=7.3 \mathrm{~Hz})$ and the signal at $\delta_{\mathrm{C}} 67.8$ (aglycone $\mathrm{C}-17)$ exhibiting that the Glc IV H-1 was linked to the $\mathrm{C}-17$ of the aglycone; the signal at $\delta_{\mathrm{H}} 4.83(1 \mathrm{H}, \mathrm{s})$ and the signal at $\delta_{\mathrm{C}} 79.3$ (Glc IV C-4) indicating that the Rha I H-1 was bound to the Glc IV C-4; the signal at $\delta_{\mathrm{H}} 4.71(1 \mathrm{H}, \mathrm{s})$ and the signal at $\delta_{\mathrm{C}} 66.9$ (Glc IV C-6) showing the Rha II H1 to be linked to the Glc IV C-6. The sugar structure of $\mathbf{1}$ previously reported should be revised. The structure of 1 was determined to be 3- $O$ - $\beta$-D-glucopyranosyl-( $1 \rightarrow 2)-\beta$-D-glucopyranosyl 17-hydroxy- $6 E, 10 E, 14 Z-(3 S)$-geranyllinalool $17-O$ - $\alpha$-L-rhamnopyranosyl- $(1 \rightarrow 4)$-[ $\alpha$-L-rhamnopyranosyl$(1 \rightarrow 6)]-\beta$-D-glucopyranoside.

Capsianoside XIII (2), an amorphous powder, $[\alpha]_{\mathrm{D}}$ $-38.9^{\circ}$, showed a peak due to $[\mathrm{M}+\mathrm{Na}]^{+}$at $\mathrm{m} / z 1108$ in positive FAB-MS and gave a molecular formula $\mathrm{C}_{50} \mathrm{H}_{84} \mathrm{O}_{25} \mathrm{Na}$ at $\mathrm{m} / \mathrm{z} 1107.5350$ by HR-FAB-MS. Compound 2 was constituted of $3 \mathrm{~mol}$ of hexosyl and $2 \mathrm{~mol}$ of deoxyhexosyl moieties based on the signals of anomeric protons at $\delta 4.20(1 \mathrm{H}$,

Table 1. Distribution of Capsianosides in Paprika and Jalapeño

\begin{tabular}{|c|c|c|c|c|c|c|c|}
\hline Capsianoside & II (1) & VIII (7) & IX (4) & $X(6)$ & XIII (2) & $\mathrm{XV}(\mathbf{3})$ & XVI (5) \\
\hline C. annuum L. var. grossum (Paprika) & $\bigcirc$ & & $\bigcirc$ & $\bigcirc$ & $\bigcirc$ & O & $\bigcirc$ \\
\hline C. аппиит L. var. аппиит (Jalapeño) & $\bigcirc$ & $\bigcirc$ & $\bigcirc$ & $\bigcirc$ & $\bigcirc$ & & \\
\hline
\end{tabular}


d, $J=7.3 \mathrm{~Hz}), 4.39(1 \mathrm{H}, \mathrm{d}, J=7.3 \mathrm{~Hz}), 4.41(1 \mathrm{H}, \mathrm{d}$, $J=7.3 \mathrm{~Hz}), 4.71(1 \mathrm{H}, \mathrm{s})$ and $4.82(1 \mathrm{H}, \mathrm{s})$. Moreover, the ${ }^{13} \mathrm{C}-$ NMR spectra exhibited five anomeric carbon signals at $\delta$ 104.6, 102.7, 102.2, 101.6 and 99.4. Compared with the NMR signals of 1, the signal due to the C-4 of Glc I appeared at $\delta_{\mathrm{C}} 81.0(+9.6 \mathrm{ppm}$ shift), while the signals due to $\mathrm{C}-3$ and $\mathrm{C}-5$ shifted by -1.5 and $-1.6 \mathrm{ppm}$, respectively. No glycosylation shift at C-2 in Glc I was observed, however. The signals due to the sugar moiety bound to $\mathrm{C}-17-\mathrm{OH}$ were superimposable on those of compound 1. The HMBC correlations between the signal at $\delta_{\mathrm{H}} 4.39(1 \mathrm{H}, \mathrm{d}, J=7.3 \mathrm{~Hz})$ and the signal at $\delta_{\mathrm{C}} 81.5$ (aglycone $\mathrm{C}-3$ ), and between the signal at $\delta_{\mathrm{H}} 4.41(1 \mathrm{H}, \mathrm{d}, J=7.3 \mathrm{~Hz})$ and that at $\delta_{\mathrm{C}} 81.0(\mathrm{Glc}$ I C-4) clarified its sugar connections to be clear. Thus, it was suggested that the sugar part is constituted of 3-O- $\beta$-D-glucopyranosyl-( $1 \rightarrow 4)$ - $\beta$-D-glucopyranosyl residues.

Capsianoside XV (3), an amorphous powder, $[\alpha]_{\mathrm{D}}-36.9^{\circ}$, showed peaks due to $[\mathrm{M}+\mathrm{Na}]^{+}$at $\mathrm{m} / \mathrm{z} 1123,[\mathrm{~m} / \mathrm{z} 1123$-hex$\mathrm{ose}^{+}$at 961, [m/z 961-deoxyhexose $]^{+}$at 815, [m/z 815-de-

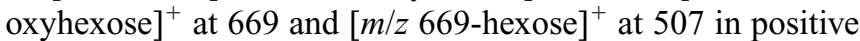
FAB-MS and gave a molecular formula $\mathrm{C}_{50} \mathrm{H}_{84} \mathrm{O}_{26} \mathrm{Na}$ at $\mathrm{m} / z$ 1123.5298 by HR-FAB-MS. Compound $\mathbf{3}$ displayed the signals from three hexosyl and two deoxyhexosyl anomeric protons $[\delta 4.21(1 \mathrm{H}, \mathrm{d}, J=7.3 \mathrm{~Hz}), 4.39(1 \mathrm{H}, \mathrm{d}, J=7.9 \mathrm{~Hz})$, $4.41(1 \mathrm{H}, \mathrm{d}, J=7.9 \mathrm{~Hz}), 4.71(1 \mathrm{H}, \mathrm{s})$ and $4.82(1 \mathrm{H}, \mathrm{s})]$ in the ${ }^{1} \mathrm{H}-\mathrm{NMR}$ spectrum. The ${ }^{13} \mathrm{C}$-NMR spectrum also exhibited five anomeric carbon signals at $\delta 104.4,102.5,102.0,101.4$ and 99.2. In a comparative study of the NMR signals with those of capsianoside II, ${ }^{5)}$ the signal due to Glc I C-4 to appear at $\delta 80.8(+9.5 \mathrm{ppm}$ shift), while the signals due to $\mathrm{C}-3$ and $\mathrm{C}-5$ shifted -0.2 and $-1.4 \mathrm{ppm}$, respectively. But no glycosylation shift at C-2 was observed, suggesting that the sugar part is constituted with $3-O-\beta$-D-glucopyranosyl$(1 \rightarrow 4)-\beta$-D-glucopyranosyl residue. The signals ascribable to

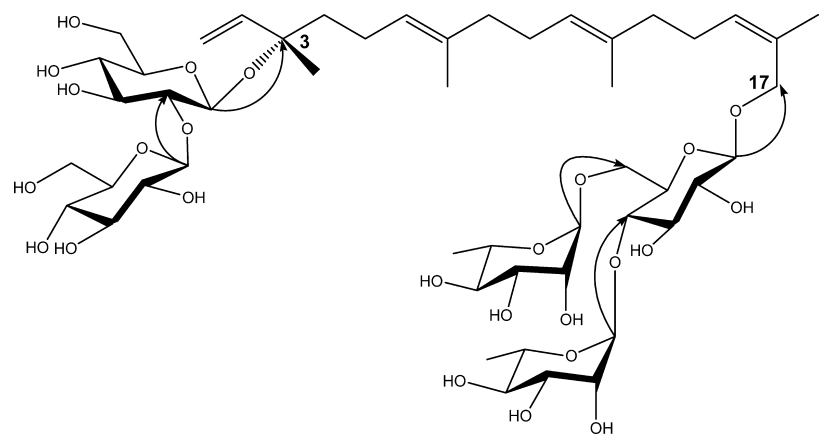

Fig. 1. Key HMBC of $\mathbf{1}$ the sugar moiety were superimposable on those of $\mathbf{2}$, however, the signals due to the aglycone moiety were different. In 3 , the signal due to one hydroxymethyl group appeared at $\delta 4.09(2 \mathrm{H}, \mathrm{s})$ instead of one methyl group in 2 . The signals due to C-6, C-7 and C-8 in 3 appeared at $\delta 129.0,139.2$ and 36.0 , respectively, showing hydroxylation shifts ${ }^{5)}$ by +3.2 , +3.7 and $-4.7 \mathrm{ppm}$, respectively. From the above evidence, a methyl group at C-19 in $\mathbf{2}$ changed to a hydroxymethyl group in $\mathbf{3}$.

Capsianoside IX (4), an amorphous powder, $[\alpha]_{\mathrm{D}}-32.7^{\circ}$, showed a peak due to $[\mathrm{M}+\mathrm{Na}]^{+}$at $m / z 1269$ in positive $\mathrm{FAB}-$ MS and gave a molecular formula $\mathrm{C}_{56} \mathrm{H}_{94} \mathrm{O}_{30} \mathrm{Na}$ at $\mathrm{m} / z$ 1269.5649 by HR-FAB-MS. Compound 4 was shown to be composed of $4 \mathrm{~mol}$ of hexosyl and $2 \mathrm{~mol}$ of deoxyhexosyl moieties from evidence due to anomeric proton signals at $\delta$ $4.20(1 \mathrm{H}, \mathrm{d}, J=7.9 \mathrm{~Hz}), 4.41(1 \mathrm{H}, \mathrm{d}, J=7.9 \mathrm{~Hz}), 4.50(1 \mathrm{H}, \mathrm{d}$, $J=7.9 \mathrm{~Hz}), 4.58(1 \mathrm{H}, \mathrm{d}, J=7.9 \mathrm{~Hz}), 4.71(1 \mathrm{H}, \mathrm{s})$ and 4.83 $(1 \mathrm{H}, \mathrm{s})$. Moreover, the ${ }^{13} \mathrm{C}-\mathrm{NMR}$ spectrum exhibited six anomeric carbon signals at $\delta 106.0,104.6,102.7,102.2$, 101.6 and 98.3. By comparing the ${ }^{13} \mathrm{C}$-NMR signals with those of 1, it was recognized that the signal of Glc I C-4 shifted to $\delta_{\mathrm{C}} 80.8(+9.4 \mathrm{ppm}$ shift), while the signals due to $\mathrm{C}-3$ and $\mathrm{C}-5$ shifted by -0.2 and $-1.0 \mathrm{ppm}$, respectively. The following HMBC showed the connections to the respective sugar: correlations between the signal at $\delta_{\mathrm{H}} 4.50(1 \mathrm{H}, \mathrm{d}$, $J=7.9 \mathrm{~Hz}$ ) and the signal at $\delta_{\mathrm{C}} 82.1$ (aglycone C-3) showing the Glc I H-1 to be linked to the $\mathrm{C}-3$ of the aglycone; the signal at $\delta_{\mathrm{H}} 4.58(1 \mathrm{H}, \mathrm{d}, J=7.9 \mathrm{~Hz})$ and that at $\delta_{\mathrm{C}} 82.8(\mathrm{Glc} \mathrm{I} \mathrm{C}-$ 2) indicating the Glc II H-1 to be linked to the C-2 of the Glc $\mathrm{I}$; the signal at $\delta_{\mathrm{H}} 4.41(1 \mathrm{H}, \mathrm{d}, J=7.9 \mathrm{~Hz})$ and that at $\delta_{\mathrm{C}} 80.8$ (Glc I C-4) showing the Glc III H-1 to be linked to C-4 of Glc I. Therefore, the 3-O-sugar part was constituted with $\beta$ D-glucopyranosyl- $(1 \rightarrow 4)$ - $[\beta$-D-glucopyranosyl- $(1 \rightarrow 2)]-\beta$-Dglucopyranosyl residue.

Capsianoside XVI (5), an amorphous powder, $[\alpha]_{\mathrm{D}}$ $-35.5^{\circ}$, showed a peak due to $[\mathrm{M}+\mathrm{Na}]^{+}$at $\mathrm{m} / \mathrm{z} 1431.6107$ (Calcd for $\mathrm{C}_{62} \mathrm{H}_{104} \mathrm{O}_{35} \mathrm{Na}, 1431.6256$ ) in HR-ESI-MS. Compound 5 showed five hexosyl and two deoxyhexosyl anomeric proton signals at $\delta 4.20(1 \mathrm{H}, \mathrm{d}, J=7.3 \mathrm{~Hz}), 4.41$ $(1 \mathrm{H}, \mathrm{d}, J=7.9 \mathrm{~Hz}), 4.51(1 \mathrm{H}, \mathrm{d}, J=7.9 \mathrm{~Hz}), 4.58(1 \mathrm{H}, \mathrm{d}$, $J=7.9 \mathrm{~Hz}), 4.58(1 \mathrm{H}, \mathrm{d}, J=7.9 \mathrm{~Hz}), 4.72(1 \mathrm{H}, \mathrm{s})$ and 4.84 $(1 \mathrm{H}, \mathrm{s})$. The ${ }^{13} \mathrm{C}-\mathrm{NMR}$ spectrum also exhibited seven anomeric carbon signals at $\delta 106.0,105.6,104.6,102.4$, 102.2, 101.6 and 98.3. The HMBC spectrum revealed the respective connectivities: the Glc I H-1 at $\delta_{\mathrm{H}} 4.51(1 \mathrm{H}, \mathrm{d}$, $J=7.9 \mathrm{~Hz}$ ) and the $\mathrm{C}-3$ at $\delta_{\mathrm{C}} 82.1$ of the aglycone; the Glc II $\mathrm{H}-1$ at $\delta_{\mathrm{H}} 4.58(1 \mathrm{H}, \mathrm{d}, J=7.9 \mathrm{~Hz})$ and the Glc I C-2 $\delta_{\mathrm{C}} 82.9$;

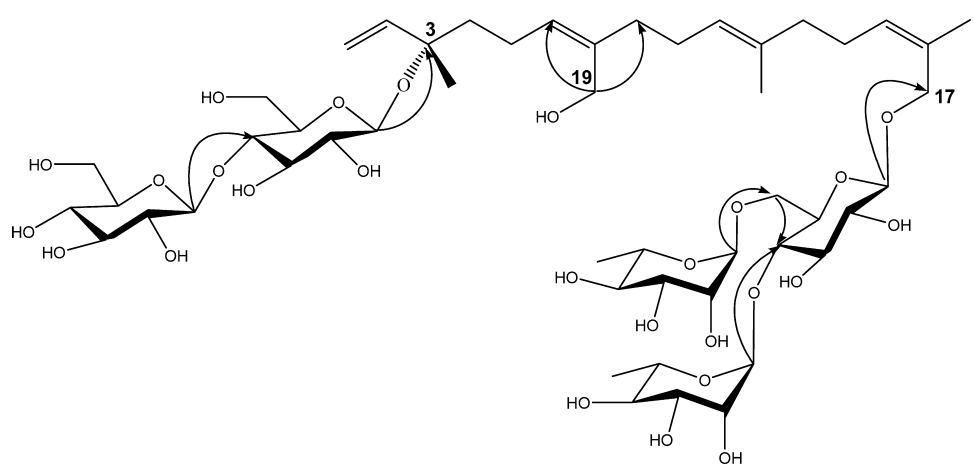

Fig. 2. Key $\mathrm{HMBC}$ of $\mathbf{3}$ 
Table 2. ${ }^{13} \mathrm{C}$-NMR Data of Compounds $\left.\mathbf{1}, \mathbf{2}, \mathbf{3}^{a}\right), \mathbf{4}$ and $\mathbf{5}$ in $\mathrm{CD}_{3} \mathrm{OD}(125 \mathrm{MHz})$

\begin{tabular}{|c|c|c|c|c|c|c|c|c|c|c|c|c|c|c|c|c|c|}
\hline Position & 1 & 2 & 3 & 4 & 5 & Position & 1 & 2 & 3 & 4 & 5 & Position & 1 & 2 & 3 & 4 & 5 \\
\hline 1 & 116.0 & 115.8 & 115.6 & 116.0 & 116.0 & Glc I-1 & 98.3 & 99.4 & 99.2 & 98.3 & 98.3 & Glc V-1 & & & & & 105.6 \\
\hline 2 & 144.4 & 144.4 & 144.1 & 144.4 & 144.4 & 2 & 83.3 & 74.9 & 74.8 & 82.8 & 82.9 & 2 & & & & & 74.9 \\
\hline 3 & 82.1 & 81.5 & 81.3 & 82.1 & 82.1 & 3 & 77.5 & 76.6 & 76.4 & 76.5 & 76.8 & 3 & & & & & 78.2 \\
\hline 4 & 43.0 & 42.6 & 42.8 & 43.0 & 43.1 & 4 & 71.4 & 81.0 & 80.8 & 80.8 & 80.9 & 4 & & & & & 71.4 \\
\hline 5 & 23.6 & 23.5 & 23.6 & 23.6 & 23.6 & 5 & 77.7 & 76.1 & 76.1 & 76.7 & 76.7 & 5 & & & & & 77.6 \\
\hline 6 & 125.9 & 125.8 & 129.0 & 125.8 & 125.8 & 6 & 62.7 & 62.2 & 62.0 & 62.7 & 62.7 & 6 & & & & & 62.8 \\
\hline 7 & 135.5 & 135.5 & 139.2 & 135.5 & 135.5 & Glc II-1 & 105.9 & & & 106.0 & 106.0 & Rha I-1 & 102.7 & 102.7 & 102.5 & 102.7 & 102.4 \\
\hline 8 & 40.8 & 40.7 & 36.0 & 40.8 & 40.8 & 2 & 76.5 & & & 76.0 & 76.6 & 2 & 72.3 & 71.4 & 71.3 & 72.2 & 72.2 \\
\hline 9 & 27.7 & 27.6 & 27.9 & 27.7 & 27.7 & 3 & 78.2 & & & 78.0 & 78.3 & 3 & 72.5 & 72.4 & 72.3 & 72.4 & 71.6 \\
\hline 10 & 125.8 & 125.9 & 125.7 & 125.9 & 125.9 & 4 & 71.7 & & & 72.3 & 72.3 & 4 & 73.8 & 74.0 & 73.7 & 73.8 & 83.3 \\
\hline 11 & 136.0 & 135.9 & 135.3 & 136.0 & 136.0 & 5 & 78.1 & & & 77.5 & 78.0 & 5 & 69.8 & 69.8 & 69.7 & 69.8 & 69.3 \\
\hline 12 & 40.8 & 40.9 & 40.9 & 40.8 & 40.9 & 6 & 62.7 & & & 62.4 & 62.4 & 6 & 17.9 & 17.9 & 17.9 & 17.9 & 18.0 \\
\hline 13 & 27.3 & 27.3 & 27.4 & 27.3 & 27.3 & Glc III-1 & & 104.6 & 104.4 & 104.6 & 104.6 & Rha II-2 & 101.6 & 101.6 & 101.4 & 101.6 & 101.6 \\
\hline 14 & 131.2 & 131.2 & 131.1 & 131.2 & 131.3 & 2 & & 75.2 & 75.1 & 74.9 & 75.3 & 2 & 72.2 & 72.2 & 72.2 & 72.3 & 72.4 \\
\hline 15 & 132.4 & 132.5 & 132.2 & 132.4 & 132.4 & 3 & & 77.9 & 77.8 & 77.9 & 78.3 & 3 & 72.4 & 72.5 & 72.2 & 72.5 & 72.4 \\
\hline 16 & 21.9 & 21.9 & 22.0 & 21.9 & 21.9 & 4 & & 72.3 & 72.4 & 71.4 & 72.3 & 4 & 74.0 & 73.8 & 74.0 & 74.0 & 74.0 \\
\hline 17 & 67.8 & 67.8 & 67.6 & 67.8 & 67.8 & 5 & & 78.1 & 78.0 & 77.5 & 77.9 & 5 & 70.6 & 70.6 & 70.5 & 70.6 & 69.8 \\
\hline 18 & 16.3 & 16.3 & 16.4 & 16.3 & 16.3 & 6 & & 62.5 & 62.4 & 62.1 & 62.2 & 6 & 18.2 & 18.2 & 18.3 & 18.2 & 18.2 \\
\hline 19 & 16.3 & 16.1 & 59.9 & 16.3 & 16.3 & Glc IV-1 & 102.2 & 102.2 & 102.0 & 102.2 & 102.2 & & & & & & \\
\hline \multirow[t]{5}{*}{20} & 23.4 & 23.3 & 23.2 & 23.5 & 23.5 & 2 & 75.2 & 74.9 & 74.8 & 75.2 & 75.5 & & & & & & \\
\hline & & & & & & 3 & 76.7 & 76.8 & 76.7 & 76.5 & 76.8 & & & & & & \\
\hline & & & & & & 4 & 79.3 & 79.4 & 79.2 & 79.3 & 79.1 & & & & & & \\
\hline & & & & & & 5 & 75.4 & 75.4 & 75.3 & 75.4 & 76.1 & & & & & & \\
\hline & & & & & & 6 & 66.9 & 66.9 & 66.8 & 66.9 & 66.9 & & & & & & \\
\hline
\end{tabular}

a) Spectra recorded in $\mathrm{CD}_{3} \mathrm{OD}$ at $100.4 \mathrm{MHz}$.

the Glc III H- 1 at $\delta_{\mathrm{H}} 4.41(1 \mathrm{H}, \mathrm{d}, J=7.9 \mathrm{~Hz})$ and the Glc I C4 at $\delta_{\mathrm{C}} 80.9$; the Glc IV H-1 at $\delta_{\mathrm{H}} 4.20(1 \mathrm{H}, \mathrm{d}, J=7.3 \mathrm{~Hz})$ and the C-17 at $\delta_{\mathrm{C}} 67.8$ of the aglycone; the Rha I H-1 at $\delta_{\mathrm{H}}$ $4.84(1 \mathrm{H}, \mathrm{s})$ and the Glc IV C-4 $\delta_{\mathrm{C}} 79.1$; the Rha II H-1 at $\delta_{\mathrm{H}}$ $4.72(1 \mathrm{H}, \mathrm{s})$ and the Glc IV C- $6 \delta_{\mathrm{C}} 66.9$; the Glc V H-1 at $\delta_{\mathrm{H}}$ $4.58(1 \mathrm{H}, \mathrm{d}, J=7.9 \mathrm{~Hz})$ and the Rha I C-4 $\delta_{\mathrm{C}} 83.3$. This suggested that the sugar part was constituted with $3-O-\beta$-D-glucopyranosyl-( $1 \rightarrow 4)$ - $[\beta$-D-glucopyranosyl- $(1 \rightarrow 2)]-\beta$-D-glucopyranosyl residue and another branched sugar part was identical to $17-O-\beta$-D-glucopyranosyl-( $1 \rightarrow 4)$ - $\alpha$-L-rhamnopyranosyl- $(1 \rightarrow 4)$-[ $\alpha$-L-rhamnopyranosyl-( $1 \rightarrow 6)]-\beta$-D-glucopyranosyl residue.

Capsianoside X (6), an amorphous powder, $[\alpha]_{\mathrm{D}}-16.7^{\circ}$, showed a peak due to $[\mathrm{M}+\mathrm{Na}]^{+}$at $m / z 1286$ in positive $\mathrm{FAB}-$ MS and gave a molecular formula $\mathrm{C}_{56} \mathrm{H}_{94} \mathrm{O}_{31} \mathrm{Na}$ at $\mathrm{m} / \mathrm{z}$ 1285.5880 by HR-FAB-MS. Compound 6 displayed five hexosyl and one deoxyhexosyl anomeric proton signals at $\delta 4.36$ $(1 \mathrm{H}, \mathrm{d}, J=7.9 \mathrm{~Hz}), 4.42(1 \mathrm{H}, \mathrm{d}, J=7.9 \mathrm{~Hz}), 4.50(1 \mathrm{H}, \mathrm{d}$, $J=7.3 \mathrm{~Hz}), 4.58(1 \mathrm{H}, \mathrm{d}, J=7.3 \mathrm{~Hz}), 4.62(1 \mathrm{H}, \mathrm{d}, J=7.9 \mathrm{~Hz})$ and $4.75(1 \mathrm{H}, \mathrm{s})$. The ${ }^{13} \mathrm{C}$-NMR spectrum also exhibited six anomeric carbon signals at $\delta 106.1,104.8,104.6,102.1$, 101.1 and 98.3. The following HMBC correlations were observed between the signal at $\delta_{\mathrm{H}} 4.50(1 \mathrm{H}, \mathrm{d}, J=7.3 \mathrm{~Hz})$ and the signal at $\delta_{\mathrm{C}} 82.1$ (aglycone C-3): the Glc I H-1 linked to the $\mathrm{C}-3$ of the aglycone; the signal at $\delta_{\mathrm{H}} 4.58(1 \mathrm{H}, \mathrm{d}$, $J=7.3 \mathrm{~Hz}$ ) and the signal at $\delta_{\mathrm{C}} 82.9$ (Glc I C-2): the Glc II H1 linked to the C-2 of the Glc I; the signal at $\delta_{\mathrm{H}} 4.42(1 \mathrm{H}, \mathrm{d}$, $J=7.9 \mathrm{~Hz}$ ) and the signal at $\delta_{\mathrm{C}} 80.8$ (Glc I C-4): the Glc III $\mathrm{H}-1$ linked to the C-4 of the Glc I; the signal at $\delta_{\mathrm{H}} 4.36(1 \mathrm{H}$, d, $J=7.9 \mathrm{~Hz}$ ) and the signal at $\delta_{\mathrm{C}} 68.3$ (aglycone C-17): the Glc IV H-1 linked to the $\mathrm{C}-17$ of the aglycone; the signal at $\delta_{\mathrm{H}} 4.62(1 \mathrm{H}, \mathrm{d}, J=7.9 \mathrm{~Hz})$ and the signal at $\delta_{\mathrm{C}} 82.1$ (Glc IV $\mathrm{C}-2)$ : $(1 \rightarrow 2)$ linkage between the two glucoses. The linkage of rhamnose to the Glc IV C-6 was also determined by the HMBC correlation between the signal at $\delta_{\mathrm{H}} 4.75(1 \mathrm{H}, \mathrm{s})$ and the signal at $\delta_{\mathrm{C}} 67.7$ (Glc IV C-6). From the above evidence, 6 was determined as 3-O- $\beta$-D-glucopyranosyl- $(1 \rightarrow 4)-[\beta$-Dglucopyranosyl- $(1 \rightarrow 2)]-\beta$-D-glucopyranosyl 17 -hydroxy$6 E, 10 E, 14 Z-(3 S)$-geranyllinalool $17-O-\beta$-D-glucopyranosyl$(1 \rightarrow 2)$-[ $\alpha$-L-rhamnopyranosyl- $(1 \rightarrow 6)]-\beta$-D-glucopyranoside.

Capsianoside VIII (7), an amorphous powder, $[\alpha]_{\mathrm{D}}$ $-20.4^{\circ}$, showed a peak due to $[\mathrm{M}+\mathrm{Na}]^{+}$at $m / z 1124$ in positive FAB-MS and gave a molecular formula $\mathrm{C}_{50} \mathrm{H}_{84} \mathrm{O}_{26} \mathrm{Na}$ at $\mathrm{m} / \mathrm{z} 1123.5348$ by HR-FAB-MS. Compound 7 showed $4 \mathrm{~mol}$ of hexosyl and one deoxyhexosyl anomeric proton signals at $\delta 4.35(1 \mathrm{H}, \mathrm{d}, J=7.9 \mathrm{~Hz}), 4.39(1 \mathrm{H}, \mathrm{d}, J=7.9 \mathrm{~Hz}), 4.41(1 \mathrm{H}$, d, $J=7.9 \mathrm{~Hz}), 4.63(1 \mathrm{H}, \mathrm{d}, J=7.9 \mathrm{~Hz})$ and $4.75(1 \mathrm{H}, \mathrm{s})$. The ${ }^{13} \mathrm{C}$-NMR spectrum exhibited five anomeric carbon signals at $\delta 104.8,104.6,102.1,101.1$ and 99.3. The sequence of the sugar part was determined by the HMBC spectrum to provide the following connections: correlations between the signal at $\delta_{\mathrm{H}} 4.39(1 \mathrm{H}, \mathrm{d}, J=7.9 \mathrm{~Hz})$ and the signal at $\delta_{\mathrm{C}} 81.5$ (aglycone C-3) indicating the Glc I H-1 to be linked to the C3 of the aglycone; the signal at $\delta_{\mathrm{H}} 4.41(1 \mathrm{H}, \mathrm{d}, J=7.9 \mathrm{~Hz})$ and the signal at $\delta_{\mathrm{C}} 81.0$ (Glc I C-4) indicating the Glc III H1 to be linked to the C-4 of the Glc I; the signal at $\delta_{\mathrm{H}} 4.35$ $(1 \mathrm{H}, \mathrm{d}, J=7.9 \mathrm{~Hz})$ and the signal at $\delta_{\mathrm{C}} 68.3$ (aglycone C-17) indicating the Glc IV $\mathrm{H}-1$ to be linked to the $\mathrm{C}-17$ of the aglycone; the signal at $\delta_{\mathrm{H}} 4.63(1 \mathrm{H}, \mathrm{d}, J=7.9 \mathrm{~Hz})$ and the signal at $\delta_{\mathrm{C}} 82.0$ (Glc IV C-2) suggesting the two glucosyl moieties have a $(1 \rightarrow 2)$ linkage; the rhamnosyl H-1 to the C6 of Glc IV was also determined by the HMBC correlation between the signal at $\delta_{\mathrm{H}} 4.75(1 \mathrm{H}, \mathrm{s})$ and the signal at $\delta_{\mathrm{C}}$ 67.6 (Glc IV C-6). From the above evidence, 7 was determined as 3 - $O$ - $\beta$-D-glucopyranosyl-( $(1 \rightarrow 4)-\beta$-D-glucopyranosyl 17-hydroxy-6E,10E,14Z-(3S)-geranyllinalool $17-O-\beta$ D-glucopyranosyl-( $(1 \rightarrow 2)$-[ $\alpha$-L-rhamnopyranosyl- $(1 \rightarrow 6)]-\beta$ D-glucopyranoside. 
Table 3. ${ }^{13} \mathrm{C}$-NMR Data of Compounds 6 and 7 in $\mathrm{CD}_{3} \mathrm{OD}(125 \mathrm{MHz})$

\begin{tabular}{|c|c|c|c|c|c|c|c|c|}
\hline Position & 6 & 7 & Position & 6 & 7 & Position & 6 & 7 \\
\hline 1 & 116.0 & 115.8 & Glc I-1 & 98.3 & 99.3 & Glc IV-1 & 101.1 & 101.1 \\
\hline 2 & 144.4 & 144.4 & 2 & 82.9 & 74.9 & 2 & 82.1 & 82.0 \\
\hline 3 & 82.1 & 81.5 & 3 & 76.1 & 76.6 & 3 & 77.5 & 77.7 \\
\hline 4 & 43.0 & 42.6 & 4 & 80.8 & 81.0 & 4 & 71.4 & 71.5 \\
\hline 5 & 23.6 & 23.5 & 5 & 76.7 & 76.1 & 5 & 76.5 & 76.6 \\
\hline 6 & 126.0 & 125.8 & 6 & 62.8 & 62.4 & 6 & 67.7 & 67.6 \\
\hline 7 & 135.4 & 135.4 & Glc II-1 & 106.1 & & Glc V-1 & 104.8 & 104.8 \\
\hline 8 & 40.8 & 40.7 & 2 & 76.6 & & 2 & 76.0 & 75.9 \\
\hline 9 & 27.7 & 27.6 & 3 & 77.8 & & 3 & 78.0 & 78.0 \\
\hline 10 & 125.8 & 125.9 & 4 & 71.4 & & 4 & 71.4 & 71.4 \\
\hline 11 & 136.0 & 135.9 & 5 & 77.8 & & 5 & 77.8 & 77.8 \\
\hline 12 & 40.9 & 40.8 & 6 & 62.1 & & 6 & 62.8 & 62.8 \\
\hline 13 & 27.3 & 27.2 & Glc III-1 & 104.6 & 104.6 & Rha 1 & 102.1 & 102.1 \\
\hline 14 & 131.2 & 131.2 & 2 & 74.9 & 74.9 & 2 & 72.2 & 72.1 \\
\hline 15 & 132.4 & 132.4 & 3 & 78.0 & 78.0 & 3 & 72.4 & 72.4 \\
\hline 16 & 21.9 & 22.0 & 4 & 71.5 & 71.4 & 4 & 74.0 & 74.0 \\
\hline 17 & 68.3 & 68.3 & 5 & 78.4 & 78.2 & 5 & 69.7 & 69.7 \\
\hline 18 & 16.3 & 16.2 & 6 & 62.4 & 62.2 & 6 & 18.1 & 18.1 \\
\hline 19 & 16.3 & 16.1 & & & & & & \\
\hline 20 & 23.4 & 23.3 & & & & & & \\
\hline
\end{tabular}
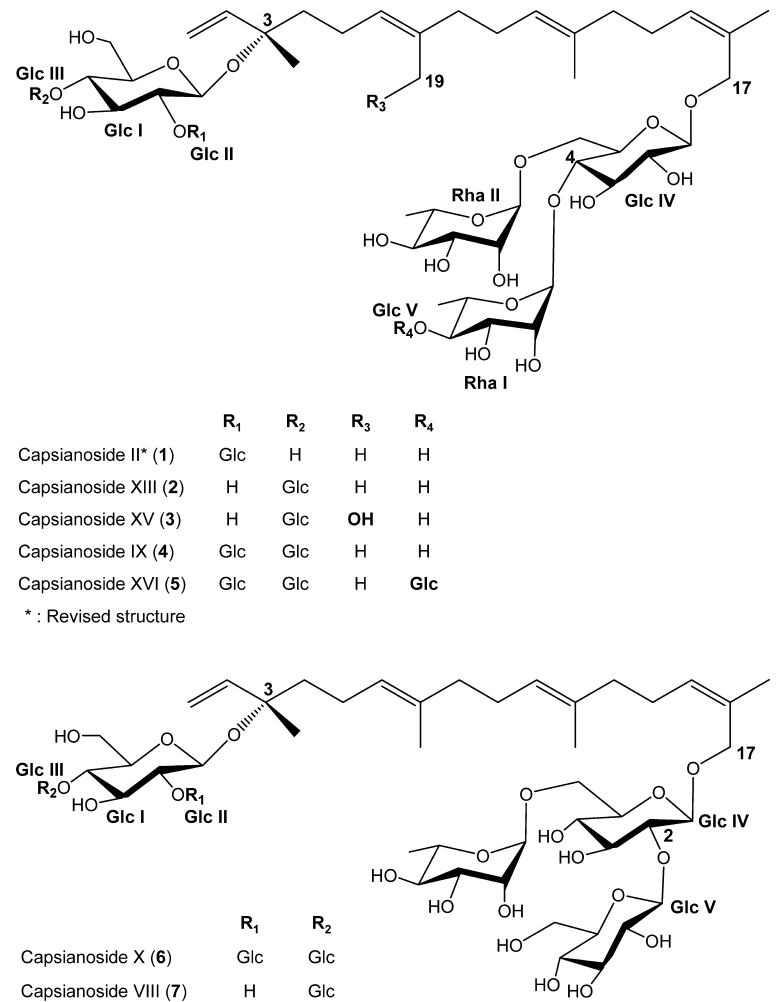

Fig. 3. Structures of Capsianosides

\section{Experimental}

The optical rotations were measured with a JASCO DIP-1000 $(l=0.5)$ automatic digital polarimeter. ${ }^{1} \mathrm{H}$ - and ${ }^{13} \mathrm{C}$-NMR spectra were measured with JEOL- $\alpha-500$ and JMX-GX 400 NMR spectrometers, and chemical shifts are given on a $\delta(\mathrm{ppm})$ scale with tetramethylsilane as an internal standard. The FAB-MS were measured with a JEOL JMS-DX303HF spectrometer and taken in a glycerol matrix containing NaI. HR-ESI-MS were measured with a JEOL JMS T-100LP spectrometer. TLC was performed on silica gel plates (Kieselgel $60 \mathrm{~F}_{254}$, Merck) and RP $\mathrm{C}_{18}$ silica gel plates (Merck). The spots on TLC were visualized by UV light $(254 / 366 \mathrm{~nm})$ and sprayed with $10 \%$ $\mathrm{H}_{2} \mathrm{SO}_{4}$, followed by heating. Column chromatography was carried out on a Diaion HP-20 (Mitsubishi Chemical Ind.), ODS (Wako Pure Chemical Industries, Ltd., Fuji Silysia Chemical, Ltd., Japan), and silica gel 60 (spheri- cal, 40-100 mm, and 230-400 mesh ASTM ; crushed, 40-63 mm, and $230-400$ mesh ASTM, Kanto Chemical Co. Inc.).

Plant Material The fruits of Paprika Capsicum annuиm L. var. grossum BAILEY and Jalapeño Capsicum annuum L. var. annuum were harvested at Nagao Farm, Kumamoto prefecture in Japan.

Extraction and Isolation The fresh Paprika $(3.15 \mathrm{~kg})$ was extracted successively with $100 \% \mathrm{MeOH}$ (three times). After evaporation of $\mathrm{MeOH}$ in vacuo, the residue $(179.55 \mathrm{~g}$ ) was suspended in water and subjected to Diaion $\mathrm{HP}-20$ using $\mathrm{H}_{2} \mathrm{O}$ and $\mathrm{MeOH}(100 \%)$. The fraction $(5.39 \mathrm{~g})$ eluted with $\mathrm{MeOH}$ was subjected to ODS (Wako) column chromatography (eluted with $50-80 \% \mathrm{MeOH}$ ). The fractions eluted with $\mathrm{MeOH} / \mathrm{H}_{2} \mathrm{O}$ were subsequently subjected to silica gel column chromatography $\left(\mathrm{CHCl}_{3} / \mathrm{MeOH} / \mathrm{H}_{2} \mathrm{O}\right.$ solvent system, $7: 3: 0.3-6: 4: 1$ ), and ODS (Chromatorex) column chromatography $\left(\mathrm{MeOH} / \mathrm{H}_{2} \mathrm{O}\right.$ solvent system, $\left.55-80 \% \mathrm{MeOH}\right)$. From the Paprika, capsianoside II (87.2 mg), IX (183.6 mg), X (25.8 mg), XIII (28.6 mg), XV $(28.5 \mathrm{mg})$ and XVI $(16.8 \mathrm{mg})$ were obtained.

The fresh Jalapeño $(6.8 \mathrm{~kg})$ was extracted with $100 \% \mathrm{MeOH}$. After evaporation of $\mathrm{MeOH}$ in vacuo, the residue $(252 \mathrm{~g})$ was suspended in water and subjected to Diaion $\mathrm{HP}-20$ using $\mathrm{H}_{2} \mathrm{O}, \mathrm{MeOH}(100 \%)$ and acetone. The fraction $(5 \mathrm{~g}$ from $19.11 \mathrm{~g}$ ) eluted with $\mathrm{MeOH}$ was subjected to ODS (Wako) column chromatography (eluted with $50-100 \% \mathrm{MeOH}$ ). The fractions eluted with $\mathrm{MeOH} / \mathrm{H}_{2} \mathrm{O}$ were subsequently subjected to silica gel column chromatography $\left(\mathrm{CHCl}_{3} / \mathrm{MeOH} / \mathrm{H}_{2} \mathrm{O}\right.$ solvent system, 9:1:0.1-6:4:1). From the Jalapeño, we obtained capsianoside II $(55.8 \mathrm{mg})$, VIII $(42.1 \mathrm{mg})$, IX (420.5 mg), X (25.9 mg), XIII (87.8 mg)

Capsianoside II (1) An amorphous powder, $[\alpha]_{\mathrm{D}}^{25}-31.2^{\circ}(c=0.19$ $\mathrm{MeOH}$ ), positive FAB-MS $\mathrm{m} / \mathrm{z}: 1108[\mathrm{M}+\mathrm{Na}]^{+}, 962,654$; positive HRFAB-MS $[\mathrm{M}+\mathrm{Na}]^{+} \mathrm{m} / z 1107.5374$ (Calcd for $\mathrm{C}_{50} \mathrm{H}_{84} \mathrm{O}_{25} \mathrm{Na}$, 1107.5199). ${ }^{1} \mathrm{H}-\mathrm{NMR}\left(\mathrm{CD}_{3} \mathrm{OD}\right) \delta: 1.26\left(3 \mathrm{H}, \mathrm{d}, J=5.5 \mathrm{~Hz}, \mathrm{Rha} \mathrm{H}_{3}-6\right), 1.27(3 \mathrm{H}, \mathrm{d}$, $J=6.1 \mathrm{~Hz}$, Rha $\left.\mathrm{H}_{3}-6\right), 1.39,1.61 \times 2,1.77$ (each $3 \mathrm{H}, \mathrm{s}, \mathrm{H}_{3}-20, \mathrm{H}_{3}-19, \mathrm{H}_{3}-18$, $\left.\mathrm{H}_{3}-16\right), 1.61\left(2 \mathrm{H}, \mathrm{m}, \mathrm{H}_{2}-4\right), 1.95-2.20\left(10 \mathrm{H}, \mathrm{m}, \mathrm{H}_{2}-5, \mathrm{H}_{2}-8, \mathrm{H}_{2}-9, \mathrm{H}_{2}-12\right.$, $\mathrm{H}_{2}-13$ ), $3.20-4.00$ (m, sugar), 4.13, 4.32 (each $1 \mathrm{H}, \mathrm{d}, J=11.6 \mathrm{~Hz}, \mathrm{H}_{2}-17$ ), $4.21,4.47,4.56$ (each $1 \mathrm{H}, \mathrm{d}, J=7.3 \mathrm{~Hz}$, Glc $\mathrm{H}-1), 4.71,4.83$ (each $1 \mathrm{H}, \mathrm{s}$, Rha H-1), 5.12×2 (each 1H, m, H-6, H-10), 5.22, 5.23 (each $1 \mathrm{H}$, br d, $\mathrm{H}_{2}-1$ ), $5.40(1 \mathrm{H}, \mathrm{t}, \mathrm{H}-14), 6.12(1 \mathrm{H}, \mathrm{dd}, J=11.0,18.3 \mathrm{~Hz}, \mathrm{H}-2)$.

Capsianoside XIII (2) An amorphous powder, $[\alpha]_{\mathrm{D}}^{25}-38.9^{\circ}(c=0.5$, $\mathrm{MeOH}$ ), positive FAB-MS $m / z: 1108[\mathrm{M}+\mathrm{Na}]^{+}$; positive HR-FAB-MS $[\mathrm{M}+\mathrm{Na}]^{+} \mathrm{m} / z$ 1107.5350 (Calcd for $\mathrm{C}_{50} \mathrm{H}_{84} \mathrm{O}_{25} \mathrm{Na}, 1107.5199$ ). ${ }^{1} \mathrm{H}-\mathrm{NMR}$ (CD $\mathrm{OD}) \delta: 1.26\left(3 \mathrm{H}, \mathrm{d}, J=6.1 \mathrm{~Hz}\right.$, Rha $\left.\mathrm{H}_{3}-6\right), 1.27(3 \mathrm{H}, \mathrm{d}, J=6.7 \mathrm{~Hz}$, Rha $\mathrm{H}_{3}-6$ ), $1.37,1.60 \times 2,1.77$ (each $3 \mathrm{H}, \mathrm{s}, \mathrm{H}_{3}-20, \mathrm{H}_{3}-19, \mathrm{H}_{3}-18, \mathrm{H}_{3}-16$ ), 1.60 $\left(2 \mathrm{H}, \mathrm{m}, \mathrm{H}_{2}-4\right), 1.95-2.20\left(10 \mathrm{H}, \mathrm{m}, \mathrm{H}_{2}-5, \mathrm{H}_{2}-8, \mathrm{H}_{2}-9, \mathrm{H}_{2}-12, \mathrm{H}_{2}-13\right), 3.20$ 4.00 (m, sugar), 4.13, 4.32 (each $1 \mathrm{H}, \mathrm{d}, J=11.6 \mathrm{~Hz}, \mathrm{H}_{2}-17$ ), 4.20, 4.39, 4.41 (each $1 \mathrm{H}, \mathrm{d}, J=7.9 \mathrm{~Hz}, \mathrm{Glc} \mathrm{H}-1$ ) , 4.71, 4.82 (each $1 \mathrm{H}, \mathrm{s}$, Rha H-1), $5.11 \times 2$ (each $1 \mathrm{H}, \mathrm{m}, \mathrm{H}-6, \mathrm{H}-10), 5.20,5.23$ (each $1 \mathrm{H}$, br d, $\left.\mathrm{H}_{2}-1\right), 5.40(1 \mathrm{H}, \mathrm{t}, \mathrm{H}-$ 14), $5.93(1 \mathrm{H}, \mathrm{dd}, J=11.0,17.7 \mathrm{~Hz}, \mathrm{H}-2)$.

Capsianoside XV (3) An amorphous powder, $[\alpha]_{\mathrm{D}}^{26}-36.9^{\circ}(c=0.67$, $\mathrm{MeOH}$ ), positive FAB-MS $m / z: 1123[\mathrm{M}+\mathrm{Na}]^{-}, 961,815,669,507$; positive HR-FAB-MS $[\mathrm{M}+\mathrm{Na}]^{+} \mathrm{m} / \mathrm{z} 1123.5298$ (Calcd for $\mathrm{C}_{50} \mathrm{H}_{84} \mathrm{O}_{26} \mathrm{Na}$, 1123.5149). ${ }^{1} \mathrm{H}-\mathrm{NMR}\left(\mathrm{CD}_{3} \mathrm{OD}\right) \delta: 1.26\left(3 \mathrm{H}, \mathrm{d}, J=6.8 \mathrm{~Hz}\right.$, Rha $\left.\mathrm{H}_{3}-6\right), 1.27$ $\left(3 \mathrm{H}, \mathrm{d}, J=5.5 \mathrm{~Hz}\right.$, Rha $\left.\mathrm{H}_{3}-6\right), 1.38,1.61,1.77$ (each $3 \mathrm{H}, \mathrm{s}, \mathrm{H}_{3}-20, \mathrm{H}_{3}-18, \mathrm{H}_{3}-$ 16), $1.63\left(2 \mathrm{H}, \mathrm{m}, \mathrm{H}_{2}-4\right), 1.99-2.20\left(10 \mathrm{H}, \mathrm{m}, \mathrm{H}_{2}-5, \mathrm{H}_{2}-8, \mathrm{H}_{2}-9, \mathrm{H}_{2}-12, \mathrm{H}_{2}-\right.$ 13), $3.20-4.01$ (m, sugar), $4.09\left(2 \mathrm{H}, \mathrm{s}, \mathrm{H}_{2}-19\right), 4.13,4.32$ (each $1 \mathrm{H}, \mathrm{d}$, $\left.J=11.6 \mathrm{~Hz}, \mathrm{H}_{2}-17\right), 4.21(1 \mathrm{H}, \mathrm{d}, J=7.3 \mathrm{~Hz}, \mathrm{Glc} \mathrm{H}-1), 4.39,4.41$ (each $1 \mathrm{H}, \mathrm{d}$, $J=7.9 \mathrm{~Hz}, \mathrm{Glc} \mathrm{H}-1), 4.71,4.82$ (each 1H, s, Rha H-1), 5.14 (1H, m, H-10), 5.20, 5.24 (each $1 \mathrm{H}$, br d, $\left.\mathrm{H}_{2}-1\right), 5.29(1 \mathrm{H}, \mathrm{t}, \mathrm{H}-6), 5.40(1 \mathrm{H}, \mathrm{t}, \mathrm{H}-14), 5.94$ $(1 \mathrm{H}, \mathrm{dd}, J=11.0,17.6 \mathrm{~Hz}, \mathrm{H}-2)$.

Capsianoside IX (4) An amorphous powder, $[\alpha]_{\mathrm{D}}^{25}-32.7^{\circ}(c=0.5$, $\mathrm{MeOH}$ ), positive FAB-MS $\mathrm{m} / z: 1269[\mathrm{M}+\mathrm{Na}]^{+}$; positive HR-FAB-MS $[\mathrm{M}+\mathrm{Na}]^{+} \mathrm{m} / z 1269.5649$ (Calcd for $\mathrm{C}_{56} \mathrm{H}_{94} \mathrm{O}_{30} \mathrm{Na}, 1269.5728$ ). ${ }^{1} \mathrm{H}-\mathrm{NMR}$ ( $\left.\mathrm{CD}_{3} \mathrm{OD}\right) \delta: 1.26\left(3 \mathrm{H}, \mathrm{d}, J=5.5 \mathrm{~Hz}\right.$, Rha $\left.\mathrm{H}_{3}-6\right), 1.27(3 \mathrm{H}, \mathrm{d}, J=6.1 \mathrm{~Hz}$, Rha $\mathrm{H}_{3}-6$ ), $1.38,1.61 \times 2,1.77$ (each $3 \mathrm{H}, \mathrm{s}, \mathrm{H}_{3}-20, \mathrm{H}_{3}-19, \mathrm{H}_{3}-18, \mathrm{H}_{3}-16$ ), 1.61 $\left(2 \mathrm{H}, \mathrm{m}, \mathrm{H}_{2}-4\right), 1.95-2.20\left(10 \mathrm{H}, \mathrm{m}, \mathrm{H}_{2}-5, \mathrm{H}_{2}-8, \mathrm{H}_{2}-9, \mathrm{H}_{2}-12, \mathrm{H}_{2}-13\right), 3.20$ 4.00 (m, sugar), 4.13, 4.32 (each $1 \mathrm{H}, \mathrm{d}, J=11.6 \mathrm{~Hz}, \mathrm{H}_{2}-17$ ), 4.20, 4.41, 4.50, 4.58 (each $1 \mathrm{H}, \mathrm{d}, J=7.9 \mathrm{~Hz}$, Glc H-1), 4.71, 4.83 (each $1 \mathrm{H}$, s, Rha H-1), $5.12 \times 2$ (each $1 \mathrm{H}, \mathrm{m}, \mathrm{H}-6, \mathrm{H}-10), 5.21,5.24$ (each $1 \mathrm{H}$, br d, $\left.\mathrm{H}_{2}-1\right), 5.40(1 \mathrm{H}$, t, H-14), 6.13 (1H, dd, $J=11.0,18.3 \mathrm{~Hz}, \mathrm{H}-2$ ).

Capsianoside XVI (5) An amorphous powder, $[\alpha]_{\mathrm{D}}^{26}-35.5^{\circ}(c=0.88$, $\mathrm{MeOH}$ ), HR-ESI-MS $[\mathrm{M}+\mathrm{Na}]^{+} \mathrm{m} / z 1431.6107$ (Calcd for $\mathrm{C}_{62} \mathrm{H}_{104} \mathrm{O}_{35} \mathrm{Na}$, 1431.6256). ${ }^{1} \mathrm{H}-\mathrm{NMR}\left(\mathrm{CD}_{3} \mathrm{OD}\right) \delta: 1.27\left(3 \mathrm{H}, \mathrm{d}, J=6.1 \mathrm{~Hz}\right.$, Rha $\left.\mathrm{H}_{3}-6\right), 1.33$ $\left(3 \mathrm{H}, \mathrm{d}, J=6.1 \mathrm{~Hz}\right.$, Rha $\left.\mathrm{H}_{3}-6\right), 1.38,1.61 \times 2,1.77$ (each $3 \mathrm{H}, \mathrm{s}, \mathrm{H}_{3}-20, \mathrm{H}_{3}-19$, $\left.\mathrm{H}_{3}-18, \mathrm{H}_{3}-16\right), 1.61\left(2 \mathrm{H}, \mathrm{m}, \mathrm{H}_{2}-4\right), 1.99-2.20\left(10 \mathrm{H}, \mathrm{m}, \mathrm{H}_{2}-5, \mathrm{H}_{2}-8, \mathrm{H}_{2}-9\right.$, $\mathrm{H}_{2}-12, \mathrm{H}_{2}-13$ ), $3.20-4.10$ (m, sugar), $4.13,4.33$ (each $1 \mathrm{H}, \mathrm{d}, J=11.6 \mathrm{~Hz}$, $\left.\mathrm{H}_{2}-17\right), 4.20(1 \mathrm{H}, \mathrm{d}, J=7.3 \mathrm{~Hz}$, Glc H-1) $4.41,4.51,4.58 \times 2($ each $1 \mathrm{H}, \mathrm{d}$, $J=7.9 \mathrm{~Hz}, \mathrm{Glc} \mathrm{H}-1), 4.72,4.84($ each $1 \mathrm{H}, \mathrm{s}$, Rha H-1), $5.12 \times 2($ each $1 \mathrm{H}, \mathrm{m}$, 
H-6, H-10), 5.21, 5.24 (each 1H, br d, $\left.\mathrm{H}_{2}-1\right), 5.40(1 \mathrm{H}, \mathrm{t}, \mathrm{H}-14), 6.13(1 \mathrm{H}$, dd, $J=10.4,17.7 \mathrm{~Hz}, \mathrm{H}-2)$.

Capsianoside X (6) An amorphous powder, $[\alpha]_{\mathrm{D}}^{25}-16.7^{\circ}(c=0.18$ $\mathrm{MeOH}$ ), positive FAB-MS $m / z: 1286\left[\mathrm{M}+\mathrm{Na}^{+}\right]^{+}$p positive HR-FAB-MS $[\mathrm{M}+\mathrm{Na}]^{+} \mathrm{m} / z$ 1285.5880 (Calcd for $\mathrm{C}_{56} \mathrm{H}_{94} \mathrm{O}_{31} \mathrm{Na}, 1285.5677$ ). ${ }^{1} \mathrm{H}-\mathrm{NMR}$ $\left(\mathrm{CD}_{3} \mathrm{OD}\right) \delta: 1.27\left(3 \mathrm{H}, \mathrm{d}, J=6.1 \mathrm{~Hz}\right.$, Rha $\left.\mathrm{H}_{3}-6\right), 1.38,1.61 \times 2,1.79$ (each $\left.3 \mathrm{H}, \mathrm{s}, \mathrm{H}_{3}-20, \mathrm{H}_{3}-19, \mathrm{H}_{3}-18, \mathrm{H}_{3}-16\right), 1.99-2.20\left(10 \mathrm{H}, \mathrm{m}, \mathrm{H}_{2}-5, \mathrm{H}_{2}-8, \mathrm{H}_{2}-9\right.$, $\left.\mathrm{H}_{2}-12, \mathrm{H}_{2}-13\right), 3.20-4.00$ (m, sugar), $4.22(1 \mathrm{H}, \mathrm{d}, J=11.6 \mathrm{~Hz}, \mathrm{H}-17), 4.29$ $(1 \mathrm{H}, \mathrm{d}, J=11.0 \mathrm{~Hz}, \mathrm{H}-17), 4.36,4.42$ (each $1 \mathrm{H}, \mathrm{d}, J=7.9 \mathrm{~Hz}$, Glc H-1), 4.50 , 4.58 (each $1 \mathrm{H}, \mathrm{d}, J=7.3 \mathrm{~Hz}$, Glc H-1), 4.62 (each $1 \mathrm{H}, \mathrm{d}, J=7.9 \mathrm{~Hz}$, Glc H1), $4.75(1 \mathrm{H}, \mathrm{s}$, Rha H-1), $5.12 \times 2$ (each $1 \mathrm{H}, \mathrm{m}, \mathrm{H}-6, \mathrm{H}-10), 5.21(1 \mathrm{H}, \mathrm{brd}$, $\mathrm{H}-1), 5.24(1 \mathrm{H}$, brd, H-1), $5.39(1 \mathrm{H}, \mathrm{t}, \mathrm{H}-14), 6.12(1 \mathrm{H}, \mathrm{dd}, J=11.0$, $18.3 \mathrm{~Hz}, \mathrm{H}-2)$.

Capsianoside VIII (7) An amorphous powder, $[\alpha]_{\mathrm{D}}^{25}-20.4^{\circ}(c=0.19$, $\mathrm{MeOH}$ ), positive FAB-MS $m / z: 1124[\mathrm{M}+\mathrm{Na}]^{+}$; positive HR-FAB-MS $[\mathrm{M}+\mathrm{Na}]^{+} \mathrm{m} / z 1123.5348$ (Calcd for $\mathrm{C}_{50} \mathrm{H}_{84} \mathrm{O}_{26} \mathrm{Na}, 1123.5149$ ). ${ }^{1} \mathrm{H}-\mathrm{NMR}$ $\left(\mathrm{CD}_{3} \mathrm{OD}\right) \delta: 1.26\left(3 \mathrm{H}, \mathrm{d}, J=6.1 \mathrm{~Hz}\right.$, Rha $\left.\mathrm{H}_{3}-6\right), 1.37,1.60,1.61,1.79$ (each $\left.3 \mathrm{H}, \mathrm{s}, \mathrm{H}_{3}-20, \mathrm{H}_{3}-19, \mathrm{H}_{3}-18, \mathrm{H}_{3}-16\right), 1.60\left(2 \mathrm{H}, \mathrm{m}, \mathrm{H}_{2}-4\right), 1.99-2.20(10 \mathrm{H}$, $\left.\mathrm{m}, \mathrm{H}_{2}-5, \mathrm{H}_{2}-8, \mathrm{H}_{2}-9, \mathrm{H}_{2}-12, \mathrm{H}_{2}-13\right), 3.20-4.00(\mathrm{~m}$, sugar $), 4.21(1 \mathrm{H}, \mathrm{d}$ $J=11.6 \mathrm{~Hz}, \mathrm{H}-17), 4.29(1 \mathrm{H}, \mathrm{d}, J=11.0 \mathrm{~Hz}, \mathrm{H}-17), 4.35,4.39,4.41,4.63$ (each $1 \mathrm{H}, \mathrm{d}, J=7.9 \mathrm{~Hz}$, Glc H-1), $4.75(1 \mathrm{H}, \mathrm{s}, \mathrm{Rha} \mathrm{H}-1), 5.12 \times 2$ (each $1 \mathrm{H}$ $\mathrm{m}, \mathrm{H}-6, \mathrm{H}-10), 5.21(1 \mathrm{H}$, br d, H-1), $5.25(1 \mathrm{H}$, br d, H-1), $5.38(1 \mathrm{H}, \mathrm{t}, \mathrm{H}-14)$, $5.93(1 \mathrm{H}, \mathrm{dd}, J=11.0,17.7 \mathrm{~Hz}, \mathrm{H}-2)$.
Acid Hydrolysis of 2 and 3 with $1 \mathrm{~N} \mathrm{HCl}$ A solution of $2(4.4 \mathrm{mg})$ and $3(2.5 \mathrm{mg})$ in $1 \mathrm{~N} \mathrm{HCl}$ was heated under reflux for $2 \mathrm{~h}$. The reaction mixture eluted with $\mathrm{H}_{2} \mathrm{O}$ and $\mathrm{MeOH}$ successively was subjected to Amberlite IRA400. The aqueous layer was subjected to HPLC analysis under the following conditions: HPLC column, COSMOSIL Sugar-D, $4.6 \mathrm{~mm}$ i.d. $\times 250 \mathrm{~mm}$ (Nacalai Tesque, Inc., Tokyo, Japan); detector, JASCO OR-2090; pump, JASCO PU-2080; solvent, $80 \% \mathrm{CH}_{3} \mathrm{CN}$; column oven, Co-2060 plus; column temperature, $30^{\circ} \mathrm{C}$. Identification of D-glucose and L-rhamnose in the aqueous layer was carried out by comparison of retention time with those of an authentic sample: D-glucose, $t_{\mathrm{R}} 12.30 \mathrm{~min}$; L-rhamnose, $t_{\mathrm{R}} 6.27 \mathrm{~min}$.

\section{References}

1) Banga I., Szent-Gyorgyi A., Biochem. J., 28, 1625-1628 (1934)

2) Molnár P., Kawase M., Satoh K., Sohara Y., Tanaka T., Tani S., Sakagami H., Nakashima H., Motohashi N., Gyémánt N., Molnár J., Phytotherapy Res., 19, 700-707 (2005).

3) Maoka T., Mochida K., Kozuka M., Ito Y., Fujiwara Y. Hashimoto K., Enjo F., Ogata M., Nobukuni Y., Tokuda H., Nishino H., Cancer Lett., 172, 103-109 (2001).

4) Ochi T., Takaishi Y., Kogure K., Yamauti I., J. Nat. Prod., 66, 1094 1096 (2003).

5) Izumitani Y., Yahara S., Nohara T., Chem. Pharm. Bull., 38, 12991307 (1990). 